УДК 681.121.833

DOI 10.36910/6775-2313-5352-2021-18-19

Ткачук В. В., Середюк О. Є., Боднар Р. Т., Саманів Л. В.

Івано-Франківський національний технічний університет нафти і газу

\title{
МОДЕЛЮВАННЯ ВПЛИВУ КОМПОНЕНТНОГО СКЛАДУ ТА ВОЛОГОСТІ ПРИРОДНОГО ГАЗУ НА ЙОГО ТЕПЛОФІЗИЧНІ ХАРАКТЕРИСТИКИ
}

Досліджено вплив вологості природного газу та компонентного складу на його теплофізичні характеристики. Наведено аналіз останніх досліджень якісних характеристик природного газу у сфері термоанемометрії. Розкрито фізичний зміст основних досліджуваних теплофізичних характеристик природного газу - теплопровідність та теплоємність, які є актуальними за умови функиіонування термоанемометричного сенсора. На підставі комп'ютерного моделювання встановлено якісний $i$ кількісний зв'язок теплофізичних характеристик природного газу з його компонентним складом і вологістю. Змодельовано вплив зміни вологості та компонентів природного газу(метан, етан, пропан, бутан, пентан, азот, вуглекислий газ) на його теплофізичні характеристики $і$ здійснено кількісний аналіз такого впливу.

Ключові слова: природний газ, компонентний склад, вологість, теплопровідність, теплоємність, термоанемометричні вимірювання.

Вступ та постановка проблеми. В теперішній час розвитку економіки держави енергоносії займають все-таки рушійну роль в діяльності підприємств, а точність кількісної оцінки енергоносіїв займає важливе місце в питаннях обліку. На сьогодні одним із головних енергоносіїв $\epsilon$ природний газ, який і надалі відіграватиме значну роль в енергозабезпеченні української та світової економіки [1]. В комерційних цілях розрахунок природного газу проводиться в об'ємних одиницях, що ставить необхідність вирішення ряду питань щодо достовірності кількісної оцінки доставленого та спожитого газу для суб'єктів комерційного процесу.

Враховуючи фізико-хімічні властивості природного газу як енергоносія, такий фізичний параметр як його об'єм не можна вважати основною одиницею при його обліку без встановлення його якісних характеристик. Відомо [2], що тиск та температура безпосередньо впливають на об'єм виміряного природного газу. Також за різних компонентних складів природний газ буде мати різні якісні та кількісні характеристики, що вже вказує на “двовимірність“" оцінювання природного газу в енергетичних одиницях [3].

При вирішенні питання кількісної оцінки спожитої енергії газу досить суттєву відповідь можуть надати термоанемометричні перетворювачі, які наділені високою точністю, швидкодією, широким діапазоном вимірювань та малою інерційністю $[4,5]$. Термоанемометричні перетворювачі безпосередньо можуть визначити об'ємну та масову витрату облікованого середовища, адже за різних якісних характеристик природного газу взаємодія давача із середовищем буде різною. В процесах обліку енергоносіїв при застосуванні термоанемометричного методу необхідно враховувати теплофізичні характеристики газового середовища, зокрема теплопровідність та теплоємність.

Таким чином, при термоанемометричних методах обліку природного газу необхідно враховувати окрім фізико-хімічних властивостей газового середовища його теплофізичні характеристики. Тому актуальними є дослідження теплофізичних властивостей природного газу не тільки при витратометрії, але й з наукової точки зору при моделюванні процесів термоанемометрії.

Аналіз останніх досліджень і публікацій. Теоретичні дослідження зміни теплофізичних параметрів природного газу при зміні компонентного складу (межі зміни: метан 89-97 \%, етан 0-6\%, пропан 0-3 \%, азот 0-3\%, вуглекислий газ 0-0,8 \%) за тисків 0,1-2 МПа і температур 283,15-303,15 К викладені у роботі [6]. Проведені експериментальні дослідження підтвердили вплив неодинакового компонентного складу природного газу на його теплофізичні характеристики та обгрунтували можливість обліку природного газу термоанемометричним методом[7].

Сучасні тенденції розвитку термоанемометрії у сфері обліку природного газу вказують, що за цим методом є майбутнє, однак він потребує подальшого удосконалення з метою 
підвищення точності і модельного врахування впливових факторів [8]. Це стосується не тільки апаратурного та конструктивного удосконалення, але і удосконалення математичних моделей, які би враховували зміну різних впливових факторів, які стосуються компонентного складу облікованого середовища. Так ні в одній з відомих нами статей не досліджується вплив вологи на функціонування термоанемометричних сенсорів. Це питання $є$ актуальним, оскільки хроматографічний метод аналізу природного газу передбачає його попереднє осушування[2], а метод змінного перепаду тиску передбачає також облік сухого природного газу з коефіцієнтом відносної вологості не більше 0,1 [9]. Тому невивченим $є$ питання впливу вологості робочого середовища на функціонування термоанемометричних сенсорів.

Перші дослідження цього напрямку викладені в роботі [10], де робочим середовищем виступало повітря. За цих умов було теоретично досліджено вплив вологості повітря на його теплофізичні характеристики при функціонуванні термоанемометричних сенсорів при зміні температури $10-40^{\circ} \mathrm{C}$, тиску $0,1 \mathrm{MПа} \mathrm{та} \mathrm{відносної} \mathrm{вологості} 10-90 \%$. За результатами моделювання встановлено, що при зростанні вологості та температури повітря відбувається збільшення його теплоємності та зменшення теплопровідності. При цьому за вищої температури вологого повітря вплив вологості є більш суттєвий на його теплопровідність та теплоємність.

Наступним напрямком теоретичних досліджень було дослідження зміни теплофізичних параметрів вологого природного газу[11]. Для теоретичних досліджень було вибрано природний газ сталого компонентного складу за масовим вмістом $(93,11 \%$ - метан, $3,23 \%$ етан, $1,45 \%$ - пропан, $0,61 \%$ - бутан, 0,12 - пентан, $0,057 \%$ - гексан, $1,13 \%$ - азот, $0,26 \%$ вуглекислий газ). Вплив вологи природного газу на зміну його теплопровідності та теплоємності проводилося за допомогою комп'ютерного моделювання за зміни температури 0 $40^{\circ} \mathrm{C}$, абсолютного тиску 0,1МПа та відносної вологості $10-90 \%$. Результати дослідження підтвердили, що волога безпосередньо впливає на зміну теплофізичних характеристик природного газу, що може бути впливовим фактором при термоанемометричних вимірюваннях. Виявлено також, що більш суттєвою є зміна теплофізичних параметрів за більших температур газового середовища.

Таким чином, зазначені наукові дослідження вказують на необхідність дослідження впливу вологи досліджуваного газового середовища на його теплофізичні характеристики при різних концентраціях вуглеводневих та невуглеводневих компонентів природного газу, що $є$ актуальним при здійсненні термоанемометричних вимірювань якісних характеристик, об'єму та енергії природного газу.

Метою роботи є моделювання впливу вологості природного газу на його теплофізичні характеристики за умови зміни якісних характеристик, тобто компонентного складу.

Виклад основного матеріалу. Виходячи 3 кінетичної теорії перенесення тепла у речовині, теплопровідність газу при стандартних значеннях тиску та температури визначається перенесенням кінетичної енергії при броунівському молекулярному русі в досліджуваному середовищі. Коефіцієнт теплопровідності $\lambda$ визнається, як добуток середньої швидкості молекул газу, середньої довжини вільного пробігу молекул, теплоємності газу при сталому тиску за відомого значення густини газу [12]:

$$
\lambda=\frac{1}{3} \bar{w} \bar{l} c_{p} \rho
$$

де $\bar{w}$ - середня швидкість переміщення молекул газу; $\bar{l}$ - середня довжина вільного пробігу молекул газу; $c_{\mathrm{p}}-$ теплоємність газу за сталого тиску; $\rho$ - густина газу.

В свою чергу, середня швидкість переміщення молекул газу напряму залежить від температури [12]:

$$
\bar{W}=\sqrt{\frac{3 R T}{\mu}},
$$

де $R$ - універсальна газова стала; $\mu$ - молекулярна маса газу; $T$ - температура.

Звідси є очевидним, що зі зростанням температури коефіцієнт теплопровідності зростає. Однак у зв'язку складності вимірювання параметрів $\bar{w}, \bar{l}$ відомими $\epsilon$ табличні значення

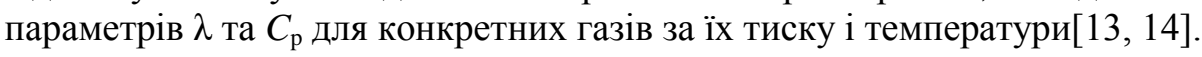

Вміст водяної пари в газі характеризується абсолютною та відносною вологістю. Під поняттям абсолютної вологості газу при заданих значеннях тиску та температури розуміється маса водяної пари, що міститься в одиниці об'єму газу. Відносна вологість є відношенням фактичного вмісту водяної пари в одиниці об'єму газу при заданих умовах тиску та

\footnotetext{
(C) Ткачук В. В., Середюк О. Є., Боднар Р. Т., Саманів Л. В.
} 
температури до його максимально можливої кількості в тому же об'ємі при певних значеннях тиску і температури[2].

3 урахуванням того, що вологий природний газ $є$ сумішшю окремих його вуглеводневих i невуглеводневих компонентів, для розрахунку значень теплофізичних характеристик використовувався метод Кея [15], який передбачає розрахунок параметрів газової суміші на базі сумування характеристик кожного компонента і його молярної концентрації в газовій суміші.

За основу при моделюванні вибрано наступний компонентний склад природного газу за об’ємним вмістом, який відображений в табл. 1.

Таблиця 1

Об'ємний та масовий компонентний склад базового природного газу

\begin{tabular}{|c|c|c|c|c|c|c|c|c|c|}
\hline Компонент & Метан & Етан & Пропан & Бутан & Пентан & Гексан & Кисень & Азот & Вугл.газ \\
\hline $\begin{array}{c}\text { Об. Вміст, } \\
C_{\mathrm{i}}, \%\end{array}$ & 96,66 & 1,79 & 0,55 & 0,17 & 0,028 & 0,011 & 0,004 & 0,67 & 0,099 \\
\hline $\begin{array}{c}\text { Мас.вміст, } \\
X_{\mathrm{i}}, \%\end{array}$ & 93,11 & 3,23 & 1,46 & 0,61 & 0,121 & 0,057 & 0,008 & 1,13 & 0,262 \\
\hline
\end{tabular}

При цьому масовий вміст компонентів для табл. 1 розраховувася за формулою[2]:

$$
X_{i}=\frac{C_{i} \cdot M_{i} \cdot 100}{\sum_{i=1}^{n} C_{i} \cdot M_{i}},
$$

де $X_{i}$ - масова доля компонента $i, \% ; C_{i}$ - об'ємна(молярна) доля компонента $i, \% ; M_{i}$ - молярна маса компонента $i$, гммоль; $n$ - число компонентів в базовій пробі.

У формулі (3) при розрахунку масової долі у параметрі $C_{\mathrm{i}}$ не враховувалися значення фактора стисливості компонентів. Тому для практичних розрахунків за умов близьких до стандартних можна вважати, що молярна концентрація компоненти практично відповідає об’ємній.

Для моделювання були сформовані такі межі зміни компонентного складу природного газу в об'ємних долях (табл. 2).

Таблиця 2

Межі зміни компонентного складу природного газу

\begin{tabular}{|l|c|c|c|c|c|c|c|}
\hline Компонент & Метан & Етан & Пропан & Бутан & Пентан & Азот & Вугл.газ \\
\hline $\begin{array}{l}\text { Межі зміни, об. } \\
\text { вмісту (\%) }\end{array}$ & $87-97$ & $1-11$ & $0,1-6$ & $0,1-4$ & $0,1-4$ & $1-11$ & $1-11$ \\
\hline
\end{tabular}

Моделювання здійснювалося за фіксованих значень тиску 0,1 МПа та температури $20^{\circ} \mathrm{C}$.

Спочатку відносно складу базового природного газу за об’ємним вмістом визначалися об'ємні долі кожного компоненту. Після цього за формулою (3) розраховувалися масові долі компоненту та їх співвідношення. Наступним кроком дискретно змінювався об'ємний вміст досліджуваного впливового компоненту, наприклад, метану і пропорційно розраховувалися об'ємні значення інших компонентів з урахуванням співвідношення між складовими, які вказані в табл. 1, щоб забезпечити досягнення загального об’єму суміші до $100 \%$. Після цього знову розраховувалися отримані масові співвідношення компонентів.

Значення теплопровідностей $\lambda$ та теплоємності $C_{\mathrm{p}}$ кожного компонента визначалися відповідно до довідкових даних[13, 14] за визначених умов моделювання.

Теплопровідність газової суміші $\lambda_{\text {см }}$ розраховувалась як сума основних компонентів газової суміші з додаванням вмісту вологи, враховуючи масовий вміст кожної складової газової суміші відповідно до правила Кея[15]:

$$
\lambda_{\text {cu }}=\lambda_{1} g_{1}+\lambda_{2} g_{2}+\ldots+\lambda_{\mathrm{n}} g_{\mathrm{n}}+\lambda_{\varphi} g_{\varphi}=\sum_{i=1}^{n} \lambda_{\mathrm{i}} g_{\mathrm{i}}+\lambda_{\varphi} g_{\varphi},
$$

де $\lambda_{i}$ - теплопровідність $i$-го компонента; $g_{\text {i }}$ - масовий вміст $i$-го компонента газової суміші; $\lambda_{\varphi}, g_{\varphi}-$ теплопровідність та масовий вміст вологи.

Для розрахунку ізобарної теплоємності газової суміші $C_{\text {р.см }}$ використаний алгоритм ідентичний як для розраунку теплопровідності, з урахуванням відповідного масового вмісту кожного компонента [15]: 


$$
C_{p c u}=C_{p 1} g_{1}+C_{p 2} g_{2}+\ldots+C_{\mathrm{pn}} g_{\mathrm{n}}+C_{\mathrm{p} \varphi} g_{\varphi}=\sum_{i=1}^{n} C_{p 1} g_{\mathrm{i}}+C_{\mathrm{p} \varphi} g_{\varphi},
$$

де $C_{\mathrm{pi}}$ - теплоємність $i$-го компонента; $g_{\mathrm{i}}$ - масовий вміст $i$-го компонента газової суміші; $C_{\mathrm{p} \varphi}, g_{\varphi}-$ ізобарна теплоємність та масовий вміст вологи.

Розрахунок параметрів $g_{i}, g_{\varphi}$ проводився за формулами:

$$
\begin{gathered}
g_{\mathrm{i}}=\frac{m_{\mathrm{i}}}{\sum_{i=1}^{n} m_{i}+m_{\varphi}}, \\
g_{\varphi}=\frac{m_{\varphi}}{\sum_{i=1}^{n} m_{i}+m_{\varphi}},
\end{gathered}
$$

де $m_{\mathrm{i}}, m_{\varphi}$ - маса $i$-го компонента природного газу і водяної пари у вологому газі відповідно.

Масовий вміст вологи в природному газі, розраховувався за формулою[15]:

$$
\rho_{\mathrm{B} . \mathrm{II}}=\frac{\varphi \cdot \rho_{\mathrm{B}, \mathrm{m} . \max }}{100},
$$

де $\varphi$ - відносна вологість природного газу, $\% ; \rho_{\text {в.п max }}$ максимальна густина водяної пари

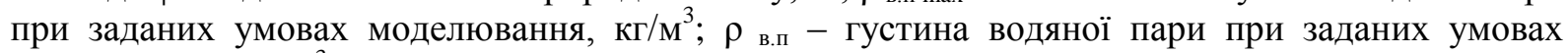
моделювання, кг $/ \mathrm{M}^{3}$.

Таким чином, використання алгоритму (3) - (8) дозволяє реалізувати тривимірне моделювання зміни параметрів $\lambda$ та $C_{\mathrm{p}}$ від вологості $\varphi$ і кожного окремого впливового параметра (метан, етан, пропан, бутан, пентан, азот, вуглекислий газ).

Результати моделювання подаються графічними ілюстраціями(рис.1 - 7) та отриманими апроксимаційними рівняннями, які подаються далі за текстом.

Моделювання зміни вмісту метану проводилося в межах $87-97 \%$, при зміні вологості $10-90 \%$ за фіксованого значення температури $20^{\circ} \mathrm{C}$ та тиску 0,1 ППа. При цьому зміна

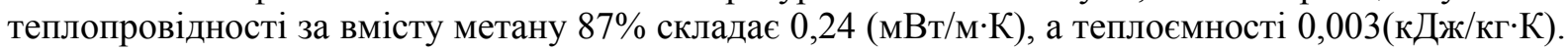
При вмісту метану 97\% теплопровідність зменшувалась на $0,28(\mathrm{MBT} / \mathrm{M} \cdot \mathrm{K})$, а теплоємність на $0,005(\kappa Д ж / к г \cdot К)$. Це відповідає зміні теплопровідності на $0,78 \%$, теплоємності на $0,14 \%$ при $87 \%$ метану, а за вмісту метану $97 \%$ зміна теплопровідності склала $0,86 \%$ та теплоємності $0,24 \%$.

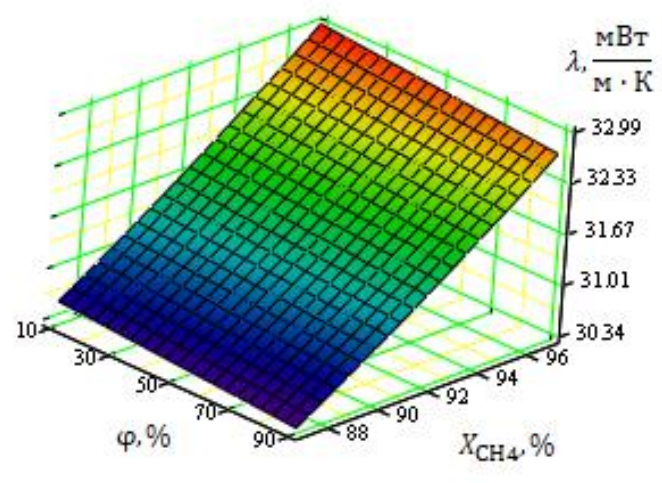

a)

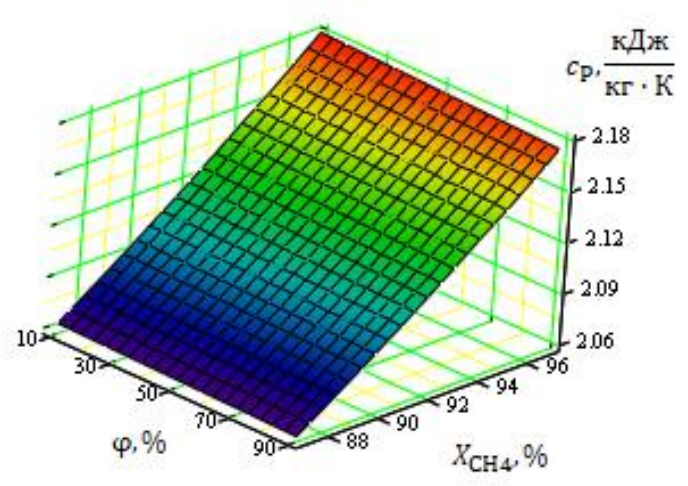

6)

Рис. 1. Графічна ілюстрація зміни теплопровідності(а),

та теплоємності (б) природного газу від відносної вологості $\varphi$ та об’ємного вмісту метану $X_{\mathrm{CH} 4}$

Результати моделювання дозволили отримати такі апроксимаційні залежності зміни теплопровідності та теплоємності від цих досліджуваних параметрів:

$$
\begin{gathered}
\lambda_{\mathrm{CH} 4}=9,8596+0,2383 \cdot X_{\mathrm{CH} 4}-0,0032 \cdot \varphi \\
C_{\mathrm{pCH} 4}=1,03998+0,011732 \cdot X_{\mathrm{CH} 4}-0,00005 \cdot \varphi
\end{gathered}
$$

де, $\lambda_{\mathrm{CH} 4}-$ теплопровідність природного газу за зміни вмісту метану; $X_{\mathrm{CH} 4}-$ вміст метану; $\varphi$ - відносна вологість природного газу.

Моделювання теплопровідності та теплоємності природного газу за зміни вмісту етану від 1 до $11 \%$, показало при 1\% етану зміну теплопровідності від 33,07 до 32,78 (мВт/м·К), теплоємності від 2,182 до 2,177 (кДж/кг К) та при $11 \%$ етану зміна була від 31,12 до 30,87 
(мВт/м·К), 2,106 до 2,102 (кДж/кг·К). У відсотках це становить зміну $0,87 \%$ та $0,24 \%, 0,8 \%$ та $0,18 \%$.

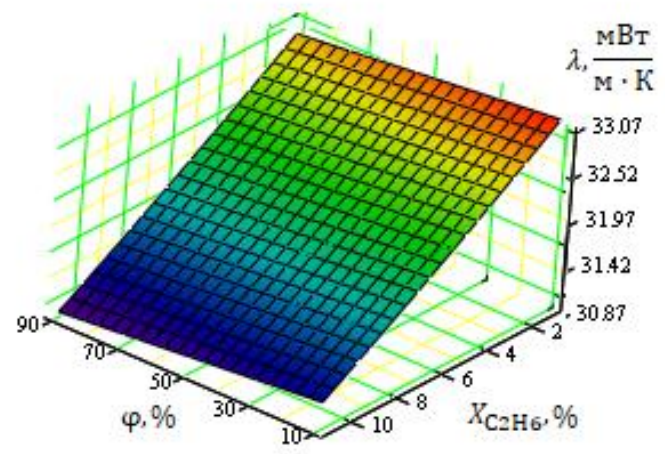

a)

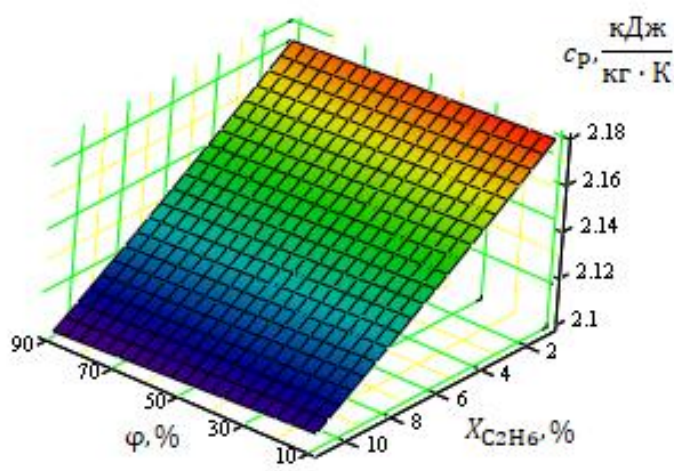

6)

Рис. 2. Графічна ілюстрація зміни теплопровідності(а),

та теплоємності (б) природного газу від відносної вологості $\varphi$ та об'ємного вмісту етану

$$
X_{\mathrm{C} 2 \mathrm{H} 6}
$$

За цим моделюванням зміни теплопровідності та теплоємності від вологості та концентрації етану(рис. 2), отримано такі апроксимаційні залежності:

$$
\begin{aligned}
\lambda_{\mathrm{C} 2 \mathrm{H} 6} & =33,2167-0,1914 \cdot X_{\mathrm{C} 2 \mathrm{H} 6}-0,0033 \cdot \varphi \\
C_{\mathrm{pC} 2 \mathrm{H} 6} & =2,187446-0,007505 \cdot X_{\mathrm{C} 2 \mathrm{H} 6}-0,000055 \cdot \varphi
\end{aligned}
$$

Результати аналогічних моделювань від решти досліджуваних впливових параметрів подано на рис. (3) - (7), де конкретизовані діапазони зміни досліджуваних параметрів.

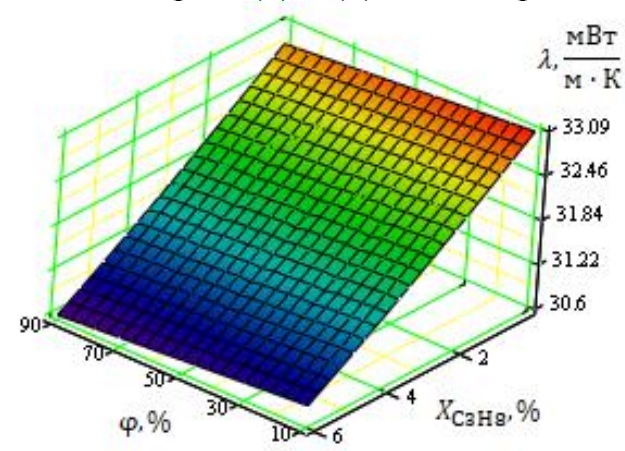

a)

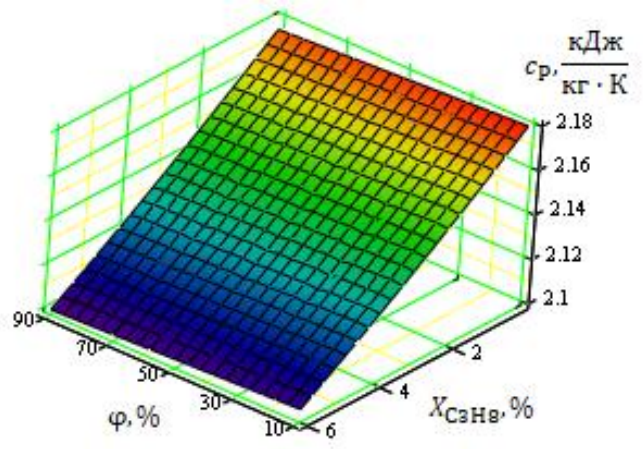

6)

Рис. 3. Графічна ілюстрація зміни теплопровідності(а), та теплоємності (б) природного газу від відносної вологості $\varphi$ та об’ємного вмісту пропану $X_{\mathrm{C} 3 \mathrm{H} 8}$

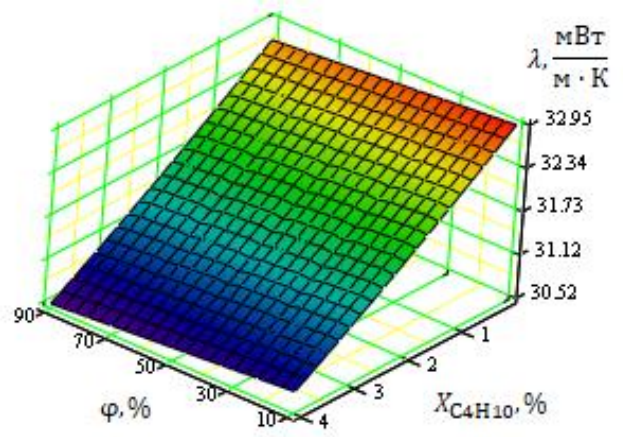

a)

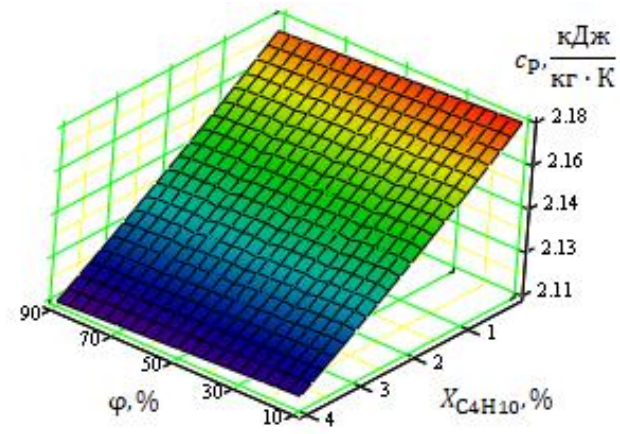

6)

Рис. 4. Графічна ілюстрація зміни теплопровідності(а), та теплоємності (б) природного газу від відносної вологості $\varphi$ та об'ємного вмісту бутану $X_{\mathrm{C} 4 \mathrm{H} 10}$ 


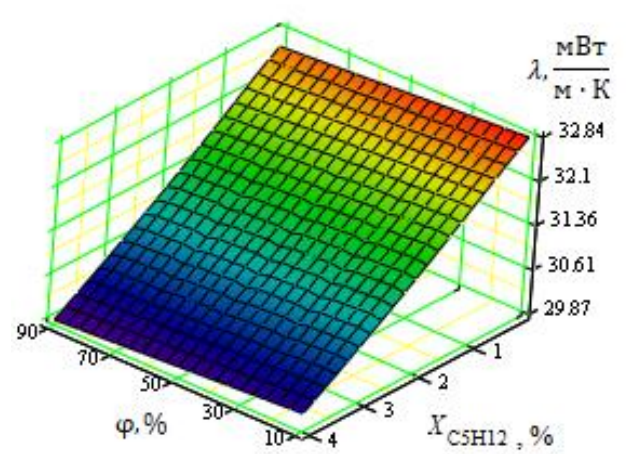

a)

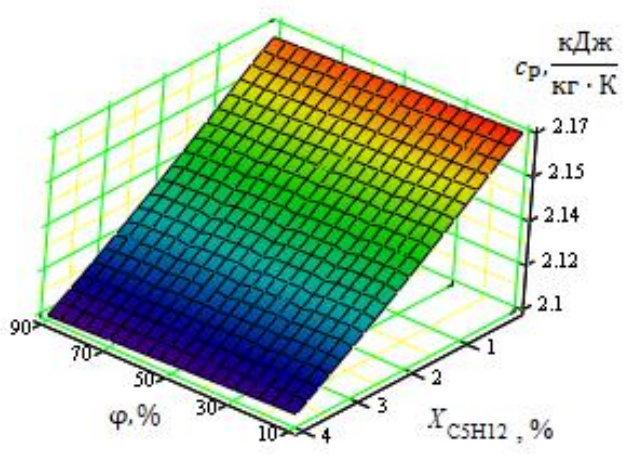

6)

Рис. 5. Графічна ілюстрація зміни теплопровідності(а), та теплоємності (б) природного газу від відносної вологості $\varphi$ та об'ємного вмісту пентану $X_{\mathrm{C} 5 \mathrm{H} 12}$

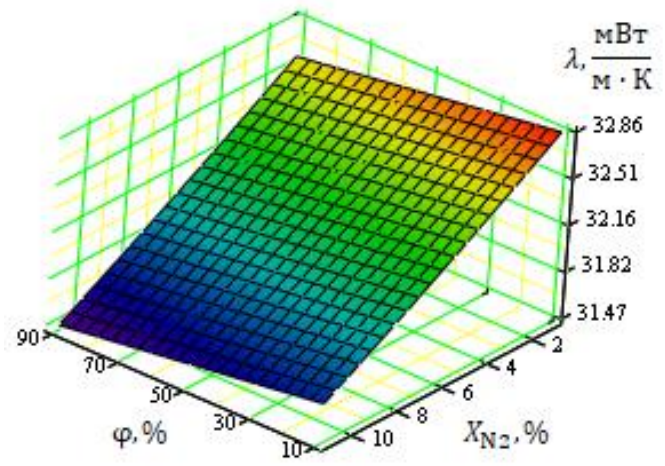

a)

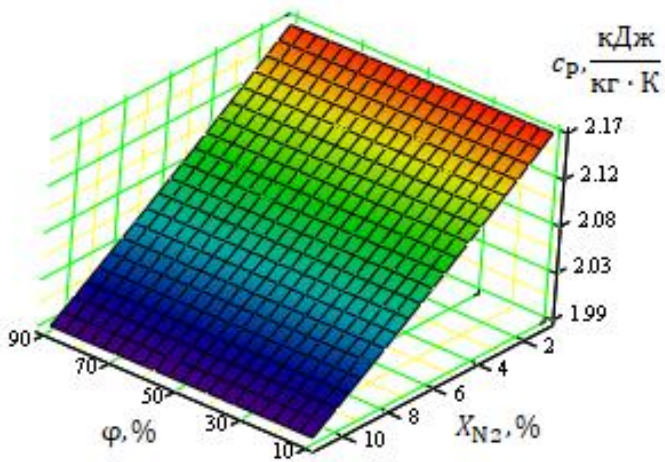

б)

Рис. 6. Графічна ілюстрація зміни теплопровідності(а),

та теплоємності (б) природного газу від відносної вологості $\varphi$ та об'ємного вмісту азоту $X_{\mathrm{N} 2}$

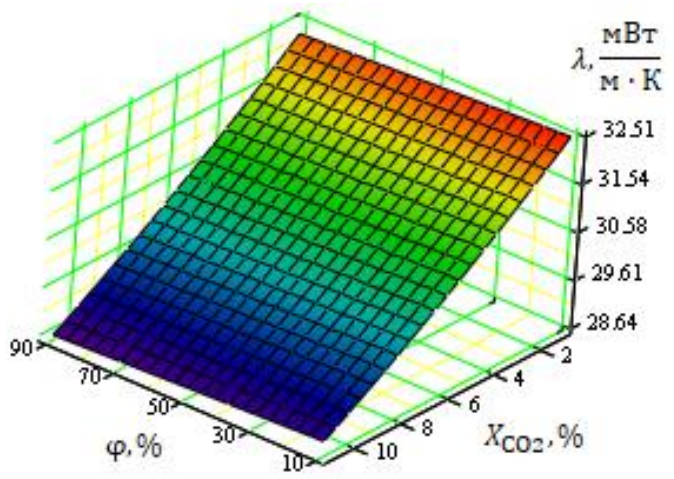

a)

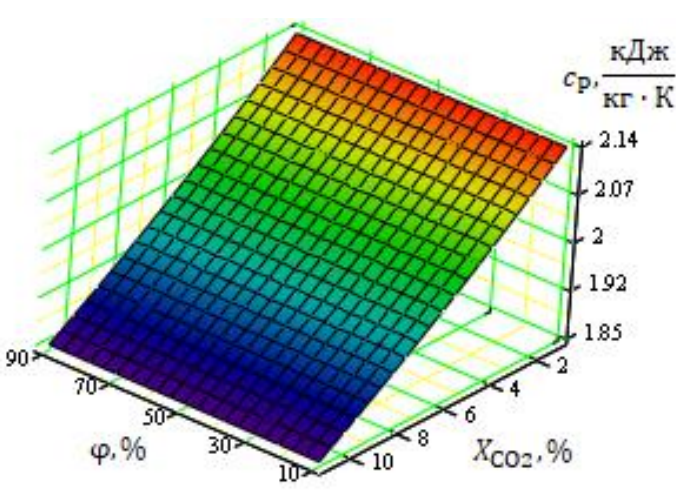

6)

Рис. 7. Графічна ілюстрація зміни теплопровідності(а), та теплоємності (б) природного газу від відносної вологості $\varphi$ та вмісту вуглекислого газу $X_{\mathrm{CO} 2}$

За поточним моделюванням отримано наступні апроксимаційні залежності зміни теплопровідності та теплоємності природного газу від вологості та концентрації окремих досліджуваних параметрів, вказаних індексами при позначенні теплопровідностей $\lambda$ та теплоємностей $\mathrm{C}_{\mathrm{p}}$ :

$$
\begin{aligned}
& \lambda_{\mathrm{C} 3 \mathrm{H} 8}=33,1153-0,3772 \cdot X_{\mathrm{C} 3 \mathrm{H} 8}-0,0033 \cdot \varphi \\
& C_{\mathrm{pC} 3 \mathrm{H} 8}=2,182351-0,012963 \cdot X_{\mathrm{C} 3 \mathrm{H} 8}-0,000056 \cdot \varphi
\end{aligned}
$$

(C) Ткачук В. В., Середюк О. Є., Боднар Р. Т., Саманів Л. В. 


$$
\begin{aligned}
& \lambda_{\mathrm{C} 4 \mathrm{H} 10}=32,9938-0,5563 \cdot X_{\mathrm{C} 4 \mathrm{H} 10}-0,0033 \cdot \varphi \\
& C_{\mathrm{pC} 4 \mathrm{H} 10}=2,177812-0,015723 \cdot X_{\mathrm{C} 4 \mathrm{H} 10}-0,000057 \cdot \varphi \\
& \lambda_{\mathrm{C} 5 \mathrm{H} 12}=32,9125-0,7035 \cdot X_{\mathrm{C} 5 \mathrm{H} 12}-0,0032 \cdot \varphi \\
& C_{\mathrm{pC} 5 \mathrm{H} 12}=2,175605-0,018682 \cdot X_{\mathrm{C} 5 \mathrm{H} 12}-0,000055 \cdot \varphi \\
& \lambda_{\mathrm{N} 2}=32,9886-0,1121 \cdot X_{\mathrm{N} 2}-0,0034 \cdot \varphi \\
& C_{\mathrm{p} 2}=2,184794-0,017846 \cdot X_{\mathrm{N} 2}-0,00004 \cdot \varphi \\
& \lambda_{\mathrm{CO} 2}=32,7991-0,3624 \cdot X_{\mathrm{CO} 2}-0,003 \cdot \varphi \\
& C_{\mathrm{p} \mathrm{CO} 2}=2,165218-0,029257 \cdot X_{\mathrm{CO} 2}-0,00002 \cdot \varphi
\end{aligned}
$$

Для узагальнення впливу кожного компонента природного газу на зміну теплофізичних властивостей проведені обчислення, які наведені в табл. 3, 4.

Таблиця 3

Зміна теплопровідності природного газу на $1 \%$ зміни відповідного компоненту в його складі за різних значень вологості (за об'ємним вмістом компоненту)

\begin{tabular}{|l|c|c|c|c|c|c|c|}
\hline$\Delta \lambda, \mathrm{MBT} /(\mathrm{M} \cdot \mathrm{K})$ & $\mathrm{CH}_{4}$ & $\mathrm{C}_{2} \mathrm{H}_{6}$ & $\mathrm{C}_{3} \mathrm{H}_{8}$ & $\mathrm{C}_{4} \mathrm{H}_{10}$ & $\mathrm{C}_{5} \mathrm{H}_{12}$ & $\mathrm{~N}_{2}$ & $\mathrm{CO}_{2}$ \\
\hline Вологість $10 \%$ & 0,24071 & 0,19492 & 0,37443 & 0,54739 & 0,68572 & 0,11325 & 0,36642 \\
\hline Вологість $90 \%$ & 0,23617 & 0,19125 & 0,36737 & 0,53707 & 0,67278 & 0,11112 & 0,35951 \\
\hline
\end{tabular}

Таблиця 4

Зміна теплоємності природного газу на 1\% зміни відповідного компоненту в його складі за різних значень вологості (за об'ємним вмістом компоненту)

\begin{tabular}{|l|c|c|c|c|c|c|c|}
\hline$\Delta \mathrm{C}_{\mathrm{p}}, \mathrm{\kappa Д}$ Кж/(кг·К) & $\mathrm{CH}_{4}$ & $\mathrm{C}_{2} \mathrm{H}_{6}$ & $\mathrm{C}_{3} \mathrm{H}_{8}$ & $\mathrm{C}_{4} \mathrm{H}_{10}$ & $\mathrm{C}_{5} \mathrm{H}_{12}$ & $\mathrm{~N}_{2}$ & $\mathrm{CO}_{2}$ \\
\hline Вологість $10 \%$ & 0,01186 & 0,00764 & 0,01287 & 0,01547 & 0,0182 & 0,01802 & 0,02959 \\
\hline Вологість $90 \%$ & 0,01164 & 0,00749 & 0,01263 & 0,01518 & 0,01786 & 0,01768 & 0,02903 \\
\hline
\end{tabular}

Результати аналізу таблиць 3,4 свідчать, що зростання вмісту компонента 3 більшою молярною масою приводить збільшення параметрів $\lambda$ та $\mathrm{C}_{\mathrm{p}}$. Однак цій закономірності не задовольняє зміна етану, оскільки його вплив є менший від зміни впливу метану. Вплив зміни азоту є найменший серед досліджуваних впливів досліджуваних компонентів. Вплив зміни вуглекислого газу є близький до впливу зміни пропану. Також виявлені загальні закономірності зменшення впливу кожного досліджуваного компонента із зростанням вологості газу. Очевидним є також незначний вплив зміни вологості природного газу на його теплофізичні параметри порівняно із впливом від зміни досліджуваних компонентів природного газу. При цьому ці закономірності якісно $є$ подібними для двох досліджуваних теплофізичних параметрів: теплопровідності і теплоємності. Отримані результати в ході комп’ютерного моделювання визначають необхідність врахування вологості природного газу та його компонентного складу при виконанні термоанемометричних вимірювань

Висновки. За використання методів комп'ютерного моделювання досліджено взаємозв'язок якісних характеристик вологості та компонентного складу природного газу 3 його теплофізичними характеристиками, зокрема теплопровідністю та теплоємністю.

Отримані регресійні залежності впливу відносної вологості та компонентного складу на теплофізичні характеристики природного газу, які вказують на зменшення теплопровідності та теплоємності зі збільшення вуглеводневої групи: етану, пропану, бутану, пентану та невуглеводневої групи - азоту та вуглекислого газу.

Здійснено чисельне моделювання впливу зміни компонентного складу природного газу на його теплофізичні параметри за різних значень його вологості.

Змодельовані залежності встановлюють важливість врахування впливу якісних та теплофізичних характеристик природного газу при його термоанемометричних дослідженнях.

Подальші дослідження будуть спрямовані на визначення впливу тиску і температури природного газу на зміну його теплофізичних властивостей.

\section{Література:}

1. Прогноз економічного і соціального розвитку України на 2021-2023 роки: Постанова Кабінету Міністрів України від 29.07.2020 № 671. Офіційний вісник України. 2020. 113 с.

2. Облік природного газу: довідник / М. П. Андріїшин, О. Є. Середюк, С. А. Чеховський [та ін..] / за ред. С.А.Чеховського. Івано-Франківськ: ПП «Сімик», 2008. 180 с. 
3. ДСТУ ISO 15112:2009. Природний газ. Визначення енергії. [Чинний від 2011-01-01]. Вид. офіц. Київ : Держспоживстандарт України, 2010. 48 с. (Національний стандарт).

4. Кремлевский П. П. Расходомеры и счетчики количества веществ: справочник. Кн. 2 СПб.: Политехника, 2004. 412 с.

5. Малісевич В. В. Контроль енергетичної цінності природного газу із застосуванням термоанемометричних перетворювачів : автореф. дис. ... канд. тех. наук. : 05.11.13. ІваноФранківськ, 2015. 20 с.

6. Середюк О. С., Малісевич В. В. Теоретичні засади застосування напірного витратоміра для визначення енергетичної цінності природного газ. Метрологія та прилади. 2014. № 5. С. 38 47.

7. Serediuk O., Malisevych V., Warsza Z. L. Termoanemometryczna metoda pomiaru wartości energetycznej gazu ziemnego. Przemysł chemiczny. 2017. V. 96. No. 11. P.2243-2246.

8. Середюк О. Є, Криницький О. С., Ткачук В. В. Сучасні тенденції розвитку термоанемометрії у сфері обліку природного газу. Український метрологічний журнал. 2020. № 3A. C. 51-55.

9. ДСТУ ГОСТ 8.585.2:2009 Метрологія. Вимірювання витрати та кількості рідини й газу із застосуванням стандартних звужувальних пристроїв. Частина 2. Діафрагми. Технічні вимоги: [Чинний від 2010-04-01]. Вид. офіц. Київ: Держстандарт України, 2009. 92 с. (державний стандарт України).

10. Середюк О. Є., Ткачук В. В., Саманів Л. В. Дослідження впливу вологості повітря на теплофізичні характеристики при функціонуванні термоанемометричних сенсорів. Приладобудування та метрологія: сучасні проблеми, тенденції розвитку : збірник тез IV Всеукр. наук.-практ. конф. (29-30 жовтня 2020 р.) : Луцьк : Луцький НТУ, 2020. С. 82-84.

11. Середюк О. Є., Ткачук В. В. Моделювання впливу вологи природного газу при термоанемометричних вимірюваннях. Прикладні науково-технічні дослідження : матеріали V міжнар. наук.-прак. конф., 5-7 квіт. 2021 р. Академія технічних наук України. Івано-Франківськ : Видавець Кушнір Г. М., 2021. С. 222-224.

12. Коротких А. Г. Теплопроводность материалов: учебное пособие. Томск: Томский политехнический университет, 2011. 97 с.

13. Варгафтик Н.Б. Справочник по теплофизическим свойствам газов и жидкостей. М.: Наука, 1972. 720 с.

14. Справочник по теплопроводности жидкостей и газов / Н.Б. Варгафтик,Л.П. Филиппов, А.А. Тарзиманов [и др.]. М.: Энергоатомиздат, 1990. 352 с.

15. Измерение и учет расхода газа: справ. пособие / В. А. Динков, 3. Т. Галиуллин, А. П. Подкопаев, В. С. Кондратьев. М. : Недра, 1979. 304 с.

Tkachuk V. V., Serediuk O. E., Bodnar R. T., Samaniv L. V. Ivano-Frankivsk National Technical University of Oil and Gas

\section{MODELING OF INFLUENCE OF COMPONENT COMPOSITION AND HUMIDITY OF NATURAL GAS ON ITS THERMOPHYSYCAL CHARACTERISTICS}

The influence of natural gas humidity and component composition on its thermophysical characteristics has been studied. The analysis of the last researches of qualitative characteristics of natural gas in the field of thermoanemometry was given. The physical meaning of the main studied thermophysical characteristics of natural gas - thermal conductivity and heat capacity was explored in the operation of the thermoanemometric sensor. Based on computer simulations, a qualitative and quantitative relationship between the thermophysical characteristics of natural gas and its component composition and humidity has been established. The influence of changes in humidity and composition of natural gas (methane, ethane, propane, butane, pentane, nitrogen, carbon dioxide) on its thermophysical characteristics was modeled and the quantitative analysis of such influence was carried out.

Key words: natural gas, component composition, humidity, thermal conductivity, heat capacity, thermoanemometric measurements.

Ткачук В. В., Середюк О. Е., Боднар Р. Т., Саманив Л. В.

Ивано-Франковский национальный технический университет нефти и газа

(C) Ткачук В. В., Середюк О. Є., Боднар Р. Т., Саманів Л. В. 


\section{МОДЕЛИРОВАНИЕ ВЛИЯНИЯ КОМПОНЕНТНОГО СОСТАВА И ВЛАЖНОСТИ ПРИРОДНОГО ГАЗА НА ЕГО ТЕПЛОФИЗИЧЕСКИЕ ХАРАКТЕРИСТИКИ}

Исследовано влияние влажности природного газа и компонентного состава на его теплофизические характеристики. Проведен анализ последних исследований качественных характеристик природного газа в сфере термоанемометрии. Раскрыто физический смысл основных исследуемых теплофизических характеристик природного газа - теплопроводность и теплоемкость, которые актуальны при условии функиионирования термоанемометрического сенсора. На основании компьютерного моделирования установлено качественная и количественная связь теплофизических характеристик природного газа с его компонентным составом и влажностью. Смоделировано влияние изменения влажности и компонентов природного газа (метан, этан, пропан, бутан, пентан, азот, углекислый газ) на его теплофизические характеристики и осуществлен количественный анализ такого воздействия.

Ключевые слова: природный газ, компонентный состав, влажсность, теплопроводность, теплоемкость, термоанемометрические измерения. 